\title{
Stay-green: a potentiality in plant breeding
}

\section{Stay-green: uma potencialidade no melhoramento genético de plantas}

\author{
Henrique de Souza Luche ${ }^{\mathrm{I}}$ José Antonio Gonzalez da Silva ${ }^{\text {II }}$ \\ Luciano Carlos da Maia ${ }^{\text {III }}$ Antonio Costa de Oliveira ${ }^{\text {III* }}$
}

\begin{abstract}
Looking at the new demands of the global agricultural scenario, the search for more productive, efficient and stress adapted genotypes has attracted attention of plant breeders regarding plants with improved physiological characteristics. Therefore, the stay-green trait has taken proeminence as an important strategy to overcome the current yield plateaus allied with yield adaptability and stability. This review has aimed to bring light the main aspects of the stay-green character, showing their employment potential of plant breeding.
\end{abstract}

Key words: breeding, delay senescence, abiotic stress.

RESUMO

Observando as novas demandas do cenário agrícola mundial, a busca por genótipos mais produtivos, eficientes e adaptados a estresses tem chamado a atenção de melhoristas de plantas na análise de plantas com melhores características fisiológicas. Nesse contexto, o caráter stay-green vem tomando destaque, como uma importante estratégia em superar os atuais tetos de produtividade, aliados à adaptabilidade e estabilidade. Esta revisão tem com objetivo trazer à luz os principais aspectos relacionados ao caráter stay-green, mostrando suas potencialidades de emprego no melhoramento genético de plantas.

Palavras-chave: melhoramento, senescência retardada, estresse abiótico.

\section{INTRODUCTION}

Plant breeding has made great progress, supplying food to the growing human population through the release of more efficient cultivars, showing adaptation to environment's improvements. However, the current agricultural scenario, in which there are increasing demands for food, strong climate change and a concern with environment harm from agricultural production, plant breeders are rethinking, investing not only in the traditional criteria, such as yield, but also in the selection of genotypes with high productive efficiency, through the understanding of crop physiology and stress adaptation (ARAUS et al., 2008).

Delay of leaf senescence, also known as stay-green character, has been identified as an important component in the genetic improvement of several crops to promote stress tolerance and yield gain (PEIGAO et al., 2006). The association between stay-green and desirable traits such as greater number of fertile tillers (AHLAWAT et al., 2008), higher number of grains per ear (LUCHE et al., 2013), higher industrial quality (SILVA et al., 2004), tolerance to abiotic (KASSAHUN et al., 2010) and biotic (JOSHI et al., 2007) stresses have been reported. However, maintenance of grain filling in the last stage of plant maturity has been considered as key to the success of stay-green genotypes. A greater capacity for grain filling in maintaining photosynthetic tissues of staygreen wheat genotypes has been observed, resulting in increased average weight of grains (SILVA et al., 2003). The delay of senescence was also identified as

IPrograma de Pós-graduação em Agronomia (PPGA), Faculdade de Agronomia Eliseu Maciel, Universidade Federal de Pelotas (UFPel), Pelotas, RS, Brasil.

IDDepartamento de Estudos Agrários, Universidade Regional do Noroeste do Estado do Rio Grande do Sul (Unijuí), Ijuí, RS, Brasil.

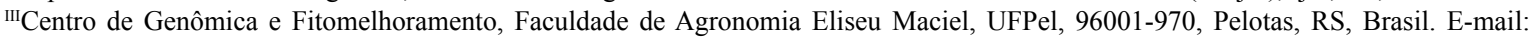
antonio.oliveira@pq.cnpq.br. "Corresponding author. 
a major factor to increase the average weight of grains of durum wheat mutants, as a result of extending the ability of producing photoassimilates towards the end of maturation (SPANO et al., 2003). Therefore, this review has aimed to bring light to major aspects of the stay-green character, showing its potential use in plant breeding.

Stay-green is the term given to a variant in which senescence is delayed in comparison to a standard reference genotype (THOMAS; HOWARTH, 2000; JOSHI et al., 2007). The stay-green character is characterized by a longer green state of the plant in the late period of grain filling, establishing a senescence pattern in which leaves and stem are the last parts to loose photosynthetic ability, providing greater production of sugars from photosynthesis (SILVA et al., 2008). Based on the increase of grain filling ability and improvement of desirable traits, it is suggested that the character results in yield gains. These gains are a consequence of increased plant photosynthetic efficiency and ability, making it an important tool (PARRY et al., 2010).

Moreover, greater ability to tolerate stresses such as high temperatures and drought was identified in stay-green genotypes, as a result of protection of photosynthetic structures to reactive oxygen species, such as superoxide and peroxide (TIAN et al., 2012).

Five distinct types of stay-green plants have been reported where the occurrence of distinct physiological and genetic modifications can be detected, but commonly two or more types of staygreen can be observed combined (THOMAS \& HOWARTH, 2000). Type A occurs when the leaves and stems maintain their photosynthetic area active for a longer period of time, experiencing a delay in plant senescence. For type B, senescence occurs in the normal period of plant development, but it occurs relatively slowly. For type C, also known as cosmetic stay-green, there is an accumulation of pigments on the surface of the organ, giving the impression that there is a reduction of senescence. However, the rate of degradation of protein and chlorophyll occurs normally below the green surface. Type D is recurrent in the herbaria and freezing of vegetables, in which the green color is maintained with leaf death via freezing, boiling or drying. Type $\mathrm{E}$ is described as the one with the highest content of chlorophyll in photosynthetic tissues, and that increased concentration results in a delay in yellowing of leaves and stems (similar to type A) and maintenance of green tissue, even with the reduced ability of fixing carbon dioxide.
Physiology of stay-green character

Senescence is a physiological process where there is a mobilization of nutrient reserves and cytokinins into fruits and seeds. This translocation leads to reduced RNA synthesis, causing changes in gene expression and thereby reducing protein synthesis, resulting in the decline of the photosynthetic capacity and cellular disorganization, leading to plant death (FLOSS, 2006). The main objective of senescence is the remobilization and recycling, so that developing tissues are resourced in the detriment of senescent tissues (BUCHANAN-WOLLASTON et al., 2003).

It is a fact that senescence is associated with the balance between hormones such as cytokinins and ethylene, and the over expression or suppression of these hormones showed changes in the timing of senescence, accelerating and retarding the process (BUCHANAN-WOLLASTON et al., 2003). In transgenic tobacco plants, which were induced for high cytokinin production, an association between higher hormone contents and higher chlorophyll and nutrient contents and maintenance of photosynthesis in older tissues, reduced the degenerating effects of senescence (JORDI et al., 2000). The application of cytokinin 6-benzylaminopurine (BAP) to wheat plants, promoted delay in plant senescence, associated with a reduced chlorophyll and soluble protein degradation rate, besides sustainning stomatal aperture and conductance and guaranteeing the maintenance of the absorption rates of $\mathrm{CO}_{2}$ (MARTÍNEZ-GUTIÉRREZ et al., 2008).

The senescence of tissues along with the remobilization of nutrients to younger or strategic tissues for survival / perpetuation of the plant, decreases photosystem II (PSII) activity and is associated with an increased content of reactive oxygen species (ROS) such as hydrogen peroxide $\left(\mathrm{H}_{2} \mathrm{O}_{2}\right)$, a marker molecule for senescence (CHEN et al., 2010). Low accumulation of reactive oxygen species such as superoxide radicals $\left(\mathrm{O}_{2}^{-}\right)$and hydrogen peroxide $\left(\mathrm{H}_{2} \mathrm{O}_{2}\right)$ were found in mutant stay-green wheat (tasgl) compared with wild types subjected to drought stress, providing greater stability of the proteins found in the walls of thylakoids (TIAN et al., 2013). The protection of the photosynthetic apparatus of chloroplasts, such as the maintenance of photosystem II (PSII) and control of content of reactive oxygen species, was also indicated as a major contribution to slowing the degeneration of tissues in genotypes wheat with functional stay-green character (LUO et al., 2006).

In Arabidopsis, the cosmetic stay-green mutant showed greater ability to control the redox potential and better maintenance of photosynthetic 
structures, even showing a reduction of some photosynthetic parameters such as ability to assimilate $\mathrm{CO}_{2}$ (GRASSL et al., 2012).

\section{Inheritance of the stay-green character}

The inheritance of the stay-green character in populations derived from the combination of stay-green and synchronized senescence wheat lines was reported (SILVA et al., 2001). The trait is governed by a single gene having two alleles, which has a partially dominant gene action, with great participation of additivity. The stay-green character has high heritability values varying from 0.75 to 0.80 , being controlled by four genes that are segregated independently, with strong contribution of additive effects (JOSHI et al., 2007). The expression of staygreen character in Mendel's peas of green cotyledon is governed by a recessive gene, $P S S G R$, which has a close relationship with the expressed gene in rice, OsSRG (SATO et al., 2007). These mutated genes are associated with absence of chlorophyll degradation, expressing the character stay-green type C. Although the analysis of 55 inbred maize lines revealed additive and non-additive effects on the governance of staygreen, a predominance of additive effects was found (COSTA et al., 2008). High participation of additivity effects in the governance of stay-green, associated to the presence of a small number of major genes allows the selection for stay-green plants with significant gains in early generations. (CUKADAR-OLMEDO \& MILLER, 1997).

Currently, breeders had the support of biotechnology to optimize the process of advancing generations, especially in the selection stage. The marker-assisted selection (MAS) technology makes use of an association between the expression of desired characters and markers present in the DNA. Thus, correlation between the markers on DNA and the traits of interest allow indirectly selecting superior genotypes. The selection marker lets one to evaluate certain characters independently of phenology and reduce time for evaluations and experimental area. Three QTLs (quantitative trait loci), located on chromosomes 1AS (QSg.bhu-1A), 3BS (QSg.bhu-3B) and 7DS (QSg.bhu-7D) associated with stay-green character were found when recombinant inbred wheat lines (RILs) from the cross of the synthetic variety stay-green "Chirya 3" synchronized Indian cultivar 'Sonalika' were analyzed (KUMMAR et al., 2010). Mapping of QTLs in a maize segregating population $\left(\mathrm{F}_{2}\right)$ from contrasting parents for the stay-green character, resulted in 14 loci associated with stay-green and also high grain yield (ZHENG et al., 2009).
In barley, nine QTLs associated with stay-green were identified, but only one of these showed a consistent connection with expression of the character in all populations and in different environments, indicating a simple genetic control of this trait. However, caution is required with the expression of QTLs given the high GxE interaction (EMEBIRI, 2013).

Four QTLs in rice (TCS4, Csfl6, Csfl9/Tcs 9 and $C s f 12$ ) were found in two RILs derived from the combination of varieties 'Suweon490' (japonica and synchronized) x 'SNU-SG1' (japonica and staygreen) and 'Andabyeo' (indica and synchronized) $\mathrm{x}$ 'SNU-SG1'. Moreover, the stay-green QTLs Csfl6 and $\operatorname{Tcs} 9$ were identified in the same position that two QTL for grain yield (Yld6 and Yld9), strengthening the link between high productivity and presence of stay-green character (FU et al., 2011).

Four QTLs (SZtgb, STG1, Stg3 and Stg4) were introduced successfully, by marker-assisted backcrossing, responsible for the governance of type A stay-green character from B35 sorghum line to R16 synchronized line, raising capacity of drought stress tolerance, which resulted from the introgression lines (KASSAHUN et al., 2010).

In a broader view, one can find in different species around four loci associated with the expression of stay-green, reinforcing the hypothesis of homology between these gene regions, which in fact reveals opportunities for comparative studies to elucidate inheritance, expression and physiology of the presence of this character. Synteny in regions from four major QTLs associated with the staygreen character in sorghum were found on the rice genome, indicating the possibility of implementation of markers associated with this trait among members of the Poaceae.

Application of the stay-green character in plant breeding

The contribution of stay-green trait have been reported in several crops, and its employment has brought the increasing in yield grain, establishment of tolerance to drought, heat and cold, which are more resistant to pathogens and less susceptibility to lodging (SILVA, 2005; ADU et al., 2011).

For sorghum, there are some studies associating stay-green with drought tolerance. The transference of stay-green from the genotype B35 to an elite variety, R16, which has a high yield potential and other desired characters was obtained employing backcrossing associated with molecular marker assisted selection (MAS). The introgression 
of the character was effective in introducing delayed senescence and drought tolerance associated with this type of senescence (KASSAHUN et al., 2010).

Highlighting the importance of genetic control of stay-green character expression in major crops, Australian Scientists from The University of Queensland applied for a patent on the plant transformation through $\operatorname{Stg} X$ genes that control expression of stay-green, order to obtain drought tolerance (EPO, 2013).

Significant correlations between grain yield and maintaining green leaf area at maturity (0.75) and leaf senescence rate $(-0.74)$ were identifyied in stress conditions, showing a superiority of stay-green when compared to synchronized hybrids (BORRELL et al., 2000).

A strong association of chlorophyll content in leaves and senescence retardation with good grain yield performance was found in maize recombinant inbred lines and other segregant populations especially under restrictive water supply conditions (CÂMARA et al., 2007; MESSMER et al., 2011).

A thorough study analyzing 936 wheat lines, resulted in a significant association between stress tolerance to high temperatures and staygreen character, finding high positive correlations between delay of senescence with tolerance to high temperatures $(\mathrm{r}=0,90)$ and with grain yield $(\mathrm{r}=0.89)$ in wheat genotypes (KUMARI et al., 2006). In wheat, the maintenance of proteins embedded in the walls of thylakoids and low levels of reactive oxygen species demonstrated the superiority of wheat mutant tasg1 tolerant to drought (TIAN et al., 2013).

In sorghum, genotypes with stay-green characteristics have been used to search better resistance to stem rot complex, disease that has difficult genetic control of resistance due to a large amount of influence factors and drought (ROSENOW, 1983; DUNCAN, 1984; EVANGELISTA \& TAGONAN, 1990; REDDY et al., 2007; BURKE at al., 2010).

Abiotic stress tolerance is a major feature of stay-green genotypes, giving stability to grain yield even in unfavorable environmental conditions (SILVA et al., 2008). Superiority of grain yield in staygreen lines when compared to synchronized sibling lines, was especially restrictive in environmental conditions such as low rainfall at the end of the cycle (LUCHE et al., 2013).

In some crops, such as wheat, is not enough to obtain high grain yields, there is the need for marketing products which have some chemical, physical and/or industrial attributes. For wheat, the baking quality is essential for marketing, this being determined by the balance between some proteins (glutenins and gliadins). A strong association between stay-green character and glutenin content in the wheat grain $(\mathrm{r}=0.87)$ was reported, indicating the use of indirect selection for industrial quality through delayed plant senescence (SILVA et al., 2004).

\section{CONCLUSION}

The use of stay-green character in breeding programs may result in significant genetic progress for attributes such as high yield, industrial quality, disease resistance and tolerance to abiotic stresses. Moreover, the pronounced additive effect in the inheritance of the stay-green character, observed in all species here described, provides an incentive for the incorporation of this trait in breeding programs.

The understanding of the physiological mechanisms associated with senescence and capacity and photosynthetic efficiency in several crops may be the key to remove the plateau of productivity associated with adaptation to unfavorable environmental conditions. Furthermore, the use of biotechnology can give new approaches about stay-green, as well as to improve your uses at breeding programs.

\section{ACKNOWLEDGEMENTS}

The authors are thankful to the Brazilian Conselho Nacional de Desenvolvimento Científico e Tecnológico (CNPqGrants \# 304181/2013-7 and 477083/2013-7), Coordenação de Aperfeiçoamento de Pessoal de Nível Superior (CAPES) and Fundação de Amparo à Pesquisa do Estado do Rio Grande do Sul (FAPERGS) for grants and fellowships.

\section{REFERENCES}

ADU, M.O. et al. 'Stay green' in wheat: comparative study of modern bread wheat and ancient wheat cultivars. ARPN Journal of Agricultural and Biological Science, v.6, n.9, p.16-24, 2011. Available from: <http://www.arpnjournals.com/jabs/research_ papers/rp_2011/jabs_0911_310.pdf>.Accessed: Apr. 2014.

AHLAWAT, S. et al. Genotypic divergence analysis for stay green characters in Wheat (Triticum aestivum L. em. Thell). South Pacific Journal of Natural Sciences, v.26, p.73-81 2008. Available from: $<$ http://www.publish.csiro.au/?act=view_file\&file_id=SP08012. pdf $>$. Accessed: Apr. 2014. doi: 10.1071/SP08012.

ARAUS, J.L et al. Breeding for yield potential and stress adaptation in cereals. Critical Reviews in Plant Science, v.27, p.377-412, 2008. Available from: <http://www.plantstress.com/articles/ up_general_files/ArausYieldDrought $\% 2008 . p d f>$. Accessed: Apr. 2014. doi:10.1080/07352680802467736.

BUCHANAN-WOLLASTON, V. et al. The molecular analysis of leaf senescence - a genomic approach. Plant Biotechnology Journal, v.1, p.3-22, 2003. Available from: <http://onlinelibrary. 
wiley.com/doi/10.1046/j.1467-7652.2003.00004.x/pdf >. Accessed: Apr. 2014. doi:10.1046/j.1467-7652.2003.00004.x.

BORRELL, A. et al. Does maintaining green leaf area in sorghum improve yield under drought? II. Dry matter production and yield. Crop Science, v.40, p.1037-1048, 2000. Available from: <https:// www.crops.org/publications/cs/abstracts/40/4/1037>. Accessed: Apr. 2014. doi:10.2135/cropsci2000.4041037x.

BURKE, J.J. et al. Selection system for the stay-green drought tolerance trait in sorghum germplasm. Agronomy Journal, v.102, n.4, p.1118-1122, 2010. Available from: <https://www.agronomy. org/publications/aj/abstracts/102/4/1118>. Accessed: Apr. 2014. doi:10.2134/agronj2009.0465.

CÂMARA, T.M.M. et al. Parâmetros genéticos de caracteres relacionados à tolerância à deficiência hídrica em milho tropical. Bragantia, v.66, n.4, p.595-603, 2007. Available from: <http://www.scielo.br/scielo.php?pid=S000687052007000400009\&script=sci arttext $>$. Accessed: Apr. 2014. doi: $10.1590 /$ S0006-87052007000 400009 .

CHEN, J. et al. Physiological characterization of 'stay green' wheat cultivars during the grain filling stage under field growing conditions. Acta Physiol Plant, v.32, p.875-882, 2010. Available from: $<$ http://link.springer.com/article/10.1007\%2 Fs11738-010-0475-0>. Accessed: Apr. 2014. doi:10.1007/s11738010-0475-0

COSTA, E.F.N. et al. Herança da senescência retardada em milho. Pesquisa Agropecuária Brasileira, v.43, n.2, p.207-213, 2008. Available from: <http://www.scielo.br/scielo.php?script $=$ sci arttext\&pid=S0100-204X2008000200008>. Accessed: Apr. 2014 doi:10.1590/S0100-204X2008000200008.

CUKADAR-OLMEDO, B.; MILLER, J.F. Inheritance of the staygreen trait in sunflower. Crop Science, v.37, n.1, p.150-153, 1997. Available from: <https://dl.sciencesocieties.org/publications/cs/ abstracts $/ 37 / 1 / \mathrm{CS} 0370010150$ ?access $=0 \& v i e w=p d f>$. Accessed: Apr. 2014. doi:10.2135/cropsci1997.0011183X003700010026x.

DUNCAN, R.R. The association of plant senescence with root and stalk diseases in sorghum. In: ICRISAT. Sorghum root and stalk rots, a critical review. Patancheru, India, 1983. p.99-110. Available from: <http://agropedialabs.iitk.ac.in/openaccess/sites/ default/files/Sorghum_root_and_stalk_rots.pdf\#page $=121>$. Accessed: Apr. 2014

EMEBIRI, L.C. QTL dissection of the loss of green colour during post-anthesis grain maturation in two-rowed barley. Theoretical and Applied Genetics, v.126, p.1873-1884, 2013. Available from: <http://download.springer.com/static/pdf/767/art\%253A10. 1007\%252Fs00122-013-2102-0.pdf?auth66=1398448976_916be dae40d0939cdeff94096f6442fe\&ext=.pdf $>$. Accessed: Apr. 2014. doi:10.1007/s00122-013-2102-0.

EPO (EUROPEAN PATENT OFFICE). Available from: $<\mathrm{http}: /$ worldwide.espacenet.com/publicationDetails/biblio?DB=EPODO $\mathrm{C} \& \mathrm{II}=0 \& \mathrm{ND}=3$ \&adjacent $=$ true $\&$ locale $=$ en $\mathrm{EP} \& \mathrm{FT}=\mathrm{D} \&$ date $=2$ $0130523 \& C C=\mathrm{WO} \& \mathrm{NR}=2013071366 \mathrm{~A} 1 \& \overline{\mathrm{KC}}=\mathrm{A} 1>$. Accessed: Aug. 2013.

EVANGELISTA, C.C.; TANGONAN, N.G. Reaction of 31 nonsenescent sorghum genotypes to stalk rot complex in southern Philippines. Tropical Pest Management, v.36, p.214-215, 1990. Available from: <http://www.tandfonline.com/doi/abs/10.1080
/09670879009371474?journalCode $=$ ttpm19\#.U1gA7vldXxI $>$. Accessed: Apr. 2014. doi:10.1080/09670879009371474.

FLOSS, E.L. Fisiologia das plantas cultivadas. 3.ed. Passo Fundo: UPF, 2006. 751p.

FU, J.D. et al. Population-specific quantitative trait loci mapping for functional stay-green trait in rice (Oryza sativa L.). Genome, v.5, p.235-243, 2011. Available from: <http://www.nrcresearchpress. com/doi/abs/10.1139/G10-113\#.U1gBmvldXxI>. Accessed: Apr. 2014. doi:10.1139/G10-113.

GRASSL, J. et al. Early events in plastid protein degradation in stay-green arabidopsis reveal differential regulation beyond the retention of LHCII and chlorophyll. Journal of Proteome Research, v.11, p.5443-5452, 2012. Available from: <http://www. ncbi.nlm.nih.gov/pubmed/23025280>. Accessed: Apr. 2014. doi: $10.1021 / \mathrm{pr} 300691 \mathrm{k}$

JORDI, W. et al. Increased cytokinin levels in transgenic PSAG12IPT tobacco plants have large direct and indirect effects on leaf senescence, photosynthesis and $\mathrm{N}$ partitioning. Plant, Cell \& Environment, v.23, p.279-289, 2000. Available from: <http:// onlinelibrary.wiley.com/doi/10.1046/j.1365-3040.2000.00544.x/ abstract>. Accessed: Apr. 2014. doi: 10.1046/j.13653040.2000.00544.x

KASSAHUN, B. et al. Stay-green expression in early generation sorghum [Sorghum bicolor (L.)Moench] QTL introgression lines. Euphytica, v.172, p.351-362, 2010. Available from: $<$ http://link. springer.com/article/10.1007\%2Fs10681-009-0108-0>. Accessed: Apr. 2014. doi: 10.1007/s10681-009-0108-0.

KUMAR, U. et al. Identification of QTLs for stay green trait in wheat (Triticum aestivum L.) in the 'Chirya 3' $\times$ 'Sonalika' population. Euphytica, v.174, n.3, p.437-445, 2010. Available from: <http:// link.springer.com/article/10.1007\%2Fs 10681-010-0155-6>. Accessed: Apr. 2014. doi: 10.1007/s10681-010-0155-6.

KUMARI, M. et al. Variation for stay green trait and its association with canopy temperature depression and yield traits under terminal heat stress in wheat. In: INTERNATIONAL WHEAT CONFERENCE. MAR DEL PLATA, 7., 2006, Argentina. Proceedings... Mar del Plata, 2006. Available from: $<$ http://link. springer.com/chapter/10.1007/1-4020-5497-1_44>. Accessed: Apr. 2014. doi: 10.1007/1-4020-5497-1 44.

LUCHE, H.S. et al. Desempenho per se e parâmetros genéticos de linhagens de trigo com expressão do caráter "stay-green". Pesquisa Agropecuária Brasileira, v.48, n.2, p.167-173, 2013. Available from: $<$ http://www.scielo.br/scielo.php?script=sci arttext\&pid=S0100-204X2013000200006 > . Accessed: Apr. 2014 doi: 10.1590/S0100-204X2013000200006.

MARTÍNEZ-GUTIÉRREZ, R. et al. Intercambio de gases y relaciones hídricas durante el retraso de la senescencia foliar de trigo (triticum aestivum 1.) por la citocinina BAP. Interciencia. Caracas, v.33 n.2, p.140-145, 2008. Available from: <http://www.scielo.org.ve/scielo. php?script $=$ sci arttext\&pid=S0378-18442008000200011\&lng=pt\&n $\mathrm{rm}=$ iso\&tlng $=\overline{\mathrm{pt}}>$. Accessed: Apr. 2014

MESSMER, R. et al. Drought stress and tropical maize: QTLs for leaf greenness, plant senescence, and root capacitance. Field Crops Research, v.124, p.93-103, 2011. Available from: <http:// www.sciencedirect.com/science/article/pii/S0378429011002097>. Accessed: Apr. 2014. doi:10.1016/j.fcr.2011.06.010. 
PARRY, M.A.J. et al. Raising yield potential of wheat. II. Increasing photosynthetic capacity and efficiency. Journal of Experimental Botany, v.62, n.2, p.453-467, 2011

PEIGAO, L. et al. Structural and biochemical mechanism responsible for the stay-green phenotype in common wheat Chinese Science Bulletin, v.51 n.21, p.2595-2603, 2006 Available from: $<$ http://csb.scichina.com:8080/kxtbe/EN/abstract/ abstract316905.shtml\#>. Accessed: Jun. 2013. doi: 10.1007/ s11434-006-2175-0

REDDY, B.V.S. et al. Evaluation of sorghum genotypes for the stay-green trait and grain yield. Journal of Semi-Arid Tropical Agricultural Research, v.3, n.1, p.1-4 2007. Available from: $<$ http://oar.icrisat.org/2590/1/Evaluation_of_sorghum.pdf $>$. Accessed: Apr. 2014

ROSENOW, D.T. Breeding for resistance to root and stalk rots in Texas. In: ICRISAT. Sorghum root and stalk rots, a critical review. Patancheru, India, 1983. p.209-217. Available from: <http:// agropedialabs.iitk.ac.in/openaccess/sites/default/files/Sorghum root_and_stalk_rots.pdf\#page=121>. Accessed: Apr. 2014 .

SATO, Y. et al. Mendel's green cotyledon gene encodes a positive regulator of the chlorophyll-degrading pathway. PNAS, v. 104 n.35, p.14169-14174, 2007. Available from: <http://www.pnas. org/content/104/35/14169.full.pdf + html>. Accessed: Apr. 2014. doi: 10.1073/pnas.0705521104.

SILVA, J.A.G. et al. Caráter stay-green e produtividade de grãos em trigo. Bragantia, v.67, n.1, p.161-167, 2008. Available from: $<$ http://www.scielo.br/scielo.php?pid=S0006-87052008000 100020\&script $=$ sci arttext $>$. Accessed: Apr. 2014. doi: 10.1590/ S0006-87052008000100020.

SILVA, J.A.G. Caráter "stay-green e técnica de duplo-haplóides como estratégia no desenvolvimento de genótipos superiores em trigo. 2005. 90f. Tese (Doutorado em Agronomia) - Universidade Federal de Pelotas, Pelotas, RS.

SILVA, S.A. et al. Análise de trilha para os componentes de rendimento de grãos em trigo. Bragantia, v.64 n.2, p.191196, 2005. Available from: <http://www.redalyc.org/articulo. oa?id=90864204>. Accessed: Apr. 2014 .

SILVA, S.A. et al. Composição de subunidades de gluteninas de alto massa molecular (HMW) em trigos portadores do caráter “stay-green". Ciência Rural, v.34, n.3, p.679-683, 2004. Available from: <http://www.scielo.br/scielo.php?script=sci artte xt\&pid=S0103-84782004000300005>. Accessed: Apr. 2014. doi: $10.1590 / \mathrm{S} 0103-84782004000300005$.

SILVA, S.A. et al. Enchimento de sementes em linhas quase isogênicas de trigo com presença e ausência do caráter "stay-green". Pesquisa Agropecuária Brasileira, v.38, n.5, p.613-618, 2003. Available from: <http://www.scielo.br/scielo.php?pid=S0100204X2003000500009\&script $=$ sci_abstract\&tlng=pt $>$. Accessed: Apr. 2014. doi: 10.1590/S0100-204X2003000500009.

SILVA, S.A. et al. Genetic basis of Stay-green trait in bread wheat. Journal of News Seeds, v.2, p.55-58, 2001. Available from: $<$ http://www.tandfonline.com/doi/abs/10.1300/J153v02n02_05\#. U1guMvldUsY>. Accessed: Apr. 2014. doi: 10.1300/ J153v02n02_05.

SPANO, G. et al. Physiological characterization of 'stay green' mutants in durum wheat. Journal of Experimental Botany, v.54, n.386, p.1415-1420, 2003. Available from: <http://jxb. oxfordjournals.org/content/54/386/1415>. Accessed: Apr. 2014. doi: $10.1093 / \mathrm{jxb} / \mathrm{erg} 150$.

TIAN, F. et al. Enhanced stability of thylakoid membrane proteins and antioxidant competence contribute to drought stress resistance in the tasg1 wheat stay-green mutant. Journal of Experimental Botany, v.64, n.6, p.1509-1520, 2013. Available from: $<$ http://jxb. oxfordjournals.org/content/early\%20/2013/01/30/jxb.ert004.full. pdf $>$. Accessed: Jun. 2013. doi: 10.1093/jxb/ert004.

TIAN, F.X. et al. Improved drought resistance in a wheat staygreen mutant tasg1under field conditions. Biologia Plantarum, v.56 n.3 p.509-515, 2012. Available from: <http://link.springer. com/article/10.1007\%2Fs10535-012-0049-7>. Accessed: Jun. 2013. doi: 10.1007/s10535-012-0049-7.

THOMAS, H.; HOWARTH, C.J. Five ways to stay green. Journal of Experimental Botany, v.51, p.329-337, 2000. Available from: $<$ http://jxb.oxfordjournals.org/content/51/suppl_1/329.full $>$. Accessed: Apr. 2014. doi: 10.1093/jexbot/51.suppl_1.329.

ZHENG, J.L. et al. QTL mapping of maize (Zea mays) staygreen traits and their relationship to yield. Plant Breeding, v.128, p.54-62, 2009. Available from: <http://onlinelibrary.wiley.com/ doi/10.1111/j.1439-0523.2008.01529.x/abstract>. Accessed: Apr. 2014. doi:10.1111/j.1439-0523.2008.01529.x. 